
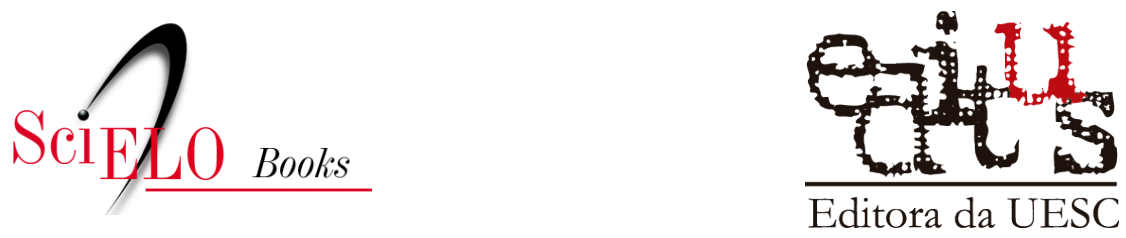

\title{
6 Palavra final: resistência
}

\author{
Ademar Cirne
}

\section{SciELO Books / SciELO Livros / SciELO Libros}

CIRNE, A. Palavra final: resistência. In: Racismo religioso em escolas da Bahia: autoafirmação e inclusão de crianças e jovens de terreiro [online]. Ilhéus, BA: Editus, 2020, pp. 171-175. Transfluência series. ISBN: 978-65-86213-16-4. https://doi.org/10.7476/9786586213294.0007.

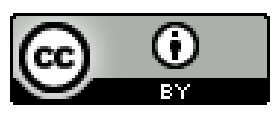

All the contents of this work, except where otherwise noted, is licensed under a Creative Commons Attribution 4.0 International license.

Todo o conteúdo deste trabalho, exceto quando houver ressalva, é publicado sob a licença Creative Commons Atribição 4.0.

Todo el contenido de esta obra, excepto donde se indique lo contrario, está bajo licencia de la licencia Creative Commons Reconocimento 4.0. 


\section{6 \\ Palavra final: resistência}

Apesar de já terem se passado mais de cem anos da assinatura da lei que aboliu a escravidão, a sociedade brasileira continua sendo um espaço de manutenção das práticas racistas contra a população negra. A ideia de superioridade racial espelhada nos conceitos eurocêntricos, que justificavam a necessidade de utilização da mão de obra negra e gratuita para a acumulação de riquezas no processo de formação do mundo capitalista durante o Antigo Regime (Século XV ao XVIII), será reforçada com as teorias científicas do final do século XIX e início do século XX que, além de construir uma justificativa civilizatória para a dominação dos povos subalternizados pelos países europeus, insistiam em adotar uma política de embranquecimento da população negra, principalmente no Brasil, como forma de eliminação do maior número de negros da sociedade brasileira, mesmo após a abolição.

Essas práticas racistas se manifestam fortemente em relação às religiões de matriz africana, o que foi observado na pesquisa realizada, ao ouvir os relatos emocionantes de algumas das crianças e jovens, que se referiram inclusive 
a muitos casos de colegas que foram motivados a deixar de frequentar a escola por causa das perseguições diárias que sofriam, relacionadas ao racismo religioso. Percebe-se com mais clareza que conceituar estes atos apenas como intolerância é muito pouco abrangente. O que se observou, na prática, é que se trata de uma ação violenta de racismo religioso, que precisa ser rápida e sistematicamente combatida e denunciada. Passou-se então a adotar o conceito de Racismo Religioso.

A escrita deste livro possibilitou o aprofundamento na formação do autor, tanto no que se refere ao tema estudado especificamente, quanto à sua própria identidade que, em verdade, dialoga com a problemática da pesquisa propriamente dita. Quanto à questão da identidade pessoal, a elaboração do memorial do autor, que constitui o quarto capítulo deste livro, "O Eu no Outro: Reconhecendo-me Negro", foi fundamental, fortalecendo suas convicções e sua autoestima a partir da retrospectiva de sua atuação profissional e cidadã.

As entrevistas e observações realizadas, no âmbito da pesquisa de que trata essa obra, também revelaram esta situação de busca do embranquecimento ou até mesmo a indução por parte de professores e gestores para que as crianças fossem mais próximas à etnia branca como forma de evitar a discriminação. Esse distanciamento da sua condição de pessoa negra também se relacionava com a negação da sua condição de religioso de matriz africana, visto que até hoje os espaços sagrados do Candomblé, ou mesmo da umbanda, estão ocupados por maioria negra, e é sobre estas pessoas que as ações do racismo religioso recaem. 
Outra conclusão a partir das entrevistas realizadas com as crianças e jovens dos terreiros pesquisados, e também, das observações realizadas durante todo nosso trabalho nas escolas, foi a de que a expulsão dos europeus, colonizadores do Brasil, não significou a destruição da ideologia eurocêntrica construída por estes, durante toda sua permanência aqui em nosso país, principalmente no que se refere aos modelos e currículos pedagógicos aplicados.

Mesmo depois de mais de um século e meio da expulsão dos portugueses, as escolas observadas ainda continuam sendo responsáveis pela aplicação de um ensino monocultural, sem muita preocupação em tentar compreender as diversidades que existem nas salas de aula, sejam estas nas questões raciais, de gênero e quilombola. Sem um processo de formação continuada dos profissionais de educação, na perspectiva dos novos conceitos educacionais, a exemplo do multiculturalismo crítico de Peter McLaren, continuamos reproduzindo em nossos alunos um modelo de educação baseado em princípios eurocêntricos subalternizantes.

Acredita-se que, enquanto não houver uma reforma das práticas educacionais e pedagógicas, não acabará o racismo religioso sofrido pelas crianças e jovens de religião de matrizes africanas, aqui observadas, e mesmo de outras religiões.

É necessário introduzir novos conceitos de educação, compreendendo a real condição da sociedade, cada dia mais globalizada e interconectada, visando construir um modelo multicultural de educação que respeite as diferenças; entenda a vontade do indivíduo; considere as suas particularidades, ou seja, construir uma ideologia respeitosa, 
inclusiva e acolhedora, entendendo a importância de não continuar tratando seres diferentes de maneira igual. Ou seja, discutir os conteúdos educacionais a partir do olhar daqueles que foram subalternizados, permitindo que estes tenham o direito de falar de si próprios, expressar-se de diferentes formas.

No terreiro se aprende pelo exemplo, pela observação e pelo fazer cotidiano, uma prática educacional diária, uma via de mão e contramão, pois como defendia o educador Paulo Freire (2000, p. 54), “Ensinar não é transferir conhecimento, mas criar as possibilidades para sua própria produção ou a sua construção".

As crianças e os jovens de terreiros participantes da pesquisa expressaram a alegria e satisfação que sentem por fazerem parte dessa comunidade religiosa. Relataram que, no terreiro, sentem-se respeitados e valorizados nas funções que exercem para o bom funcionamento da casa, assim como na realização das obrigações religiosas.

Portanto, pode-se concluir que o espaço de educação formal atual precisa ser modificado, aproximando-se mais do modelo de educação não formal que existe nos terreiros, e de métodos como o adotado por Paulo Freire, citado anteriormente, em termos de metodologia de aprendizado. O Multiculturalismo crítico, adotado como referência nesta pesquisa é, sem dúvida, um método a ser considerado e adotado, com as adaptações a cada lugar e cada tempo.

Espera-se que este livro possa ser um instrumento de combate às práticas de racismo religioso, de avanço para métodos curriculares e práticas mais inclusivas nas 
escolas e também abra espaço para novas pesquisas e projetos acadêmicos, que contribuam com o fim desse modelo eurocêntrico de educação que permanece nas salas de aula, possibilitando a construção de uma sociedade mais justa e igualitária, onde ninguem possa mais estar submetido a uma dominação de um grupo superior que diz não ter preconceito porque tolera a religiosidade dos outros grupos, por ele considerados inferiores.

Os religiosos de matriz africana não querem ser apenas tolerados, exigem que sejam definitivamente respeitados na sua crença, nos seus ritos e na sua ancestralidade. 